\title{
An Experimental Study of Welded Bar Sleeve Wall Panel Connection under Tensile, Shear, and Flexural Loads
}

\author{
Jen Hua Ling ${ }^{1), *}\left(\mathbb{0}\right.$, Ahmad Baharuddin Abd. Rahman ${ }^{2)}$, Izni Syahrizal Ibrahim²), and \\ Zuhairi Abdul Hamid ${ }^{3}$
}

(Received November 15, 2016, Accepted May 8, 2017, Published online September 12, 2017)

\begin{abstract}
This paper presents an experimental study of a new grouted splice connection for wall panels, called Welded Bar Sleeve (WBS). The connections were made from steel pipes and tested with incremental tensile, shear and flexural loads until failure. The aim is to determine the behaviour of the connection under the three load cases. For this, the connections are evaluated in terms of the load-displacement responses, ultimate capacities, ductility responses and some feasibility assessment criteria. WBS was found to provide sufficient strength at the bar embedded length of 8,8 and 11 times the bar diameter under tensile, shear and flexural loads, respectively. It is effective under tension, but could only service up to $1 / 3$ of its ultimate shear capacity. Flexural load is the most critical load case for the connection. For this, further enhancements are required when subjected to shear and flexural loads.
\end{abstract}

Keywords: grouted splice sleeve, precast wall connection, tensile, shear and flexural loads, confinement effect, feasibility study.

\section{List of Symbols}

$d_{b} \quad$ Diameter of bar embedded in the sleeve, $\mathrm{mm}$

$d_{\text {se }} \quad$ Outer diameter of sleeve, $\mathrm{mm}$

$d_{s i} \quad$ Inner diameter of sleeve, $\mathrm{mm}$

$d_{w b} \quad$ Diameter of bar welded to WBS, mm

$f_{s y} \quad$ Nominal yield stress of spliced bar, $\mathrm{N} / \mathrm{mm}^{2}$

$f_{u, b} \quad$ Ultimate tensile stress of bar, $\mathrm{N} / \mathrm{mm}^{2}$

$f_{u, c} \quad$ Ultimate compressive stress of concrete, $\mathrm{N} / \mathrm{mm}^{2}$

$f_{u, g} \quad$ Ultimate compressive stress of grout, $\mathrm{N} / \mathrm{mm}^{2}$

$f_{u, m} \quad$ Ultimate compressive stress of mortar, $\mathrm{N} / \mathrm{mm}^{2}$

$H \quad$ Height of the upper panel, mm

$l_{b} \quad$ Bar embedded length in sleeve, $\mathrm{mm}$

$l_{s l} \quad$ Length of sleeve, $\mathrm{mm}$

$t_{s l} \quad$ Thickness of sleeve, $\mathrm{mm}$

$P_{s v} \quad$ Service load of specimen, $\mathrm{kN}$

$P_{u} \quad$ Ultimate capacity of specimen, $\mathrm{kN}$

$P_{u, f t} \quad$ Ultimate capacity of wall assembly specimen under flexural load, $\mathrm{kN}$

$P_{u, s t} \quad$ Ultimate capacity of wall assembly specimen under shear load, $\mathrm{kN}$
$P_{u, t t} \quad$ Ultimate capacity of grouted splice specimen under tensile load, $\mathrm{kN}$

$P_{y} \quad$ Yield strength of specimen, $\mathrm{kN}$

$R_{d} \quad$ Ductility ratio

$R_{d f} \quad$ Drift ratio

$R_{S} \quad$ Strength ratio

$R_{s v} \quad$ Serviceability ratio

$R_{y} \quad$ Yield ratio

$\delta_{u} \quad$ Displacement at failure, $\mathrm{mm}$

$\delta_{u, f t} \quad$ Drift of upper wall panel at failure under flexural load, mm

$\delta_{u, s t, b 1}$ Horizontal displacement of bar 1 at failure under shear load, mm

$\delta_{u, s t, b 2}$ Horizontal displacement of bar 2 at failure under shear load, mm

$\delta_{u, t t} \quad$ Displacement of bar at failure under tensile load, $\mathrm{mm}$

$\delta_{y} \quad$ Displacement at yield, $\mathrm{mm}$

\section{Introduction}

Grouted splice sleeve is a mechanical coupler used to connect steel bars. A typical grouted splice consists of two steel bars, a sleeve and some grout (Fig. 1). The steel bars are bonded with non-shrink and high strength grout in the sleeve. The sleeve acts as a confinement body to resist the lateral expansion of the grout and control the propagation of the splitting cracks surrounding the bar (Fig. 2), and thus, enhances the bond between the bar and the grout. In 


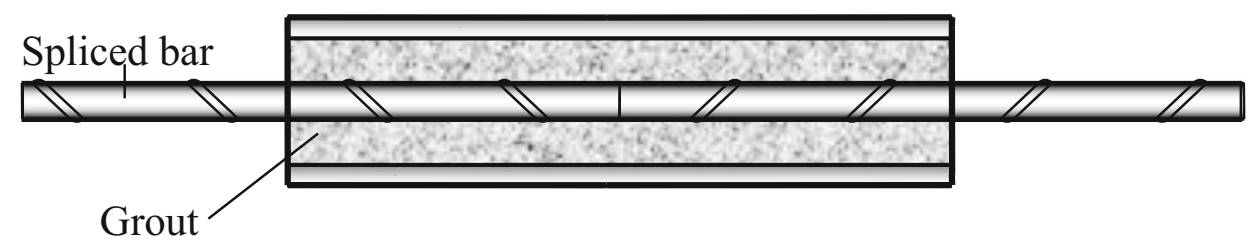

Fig. 1 Components of a typical grouted splice sleeve.

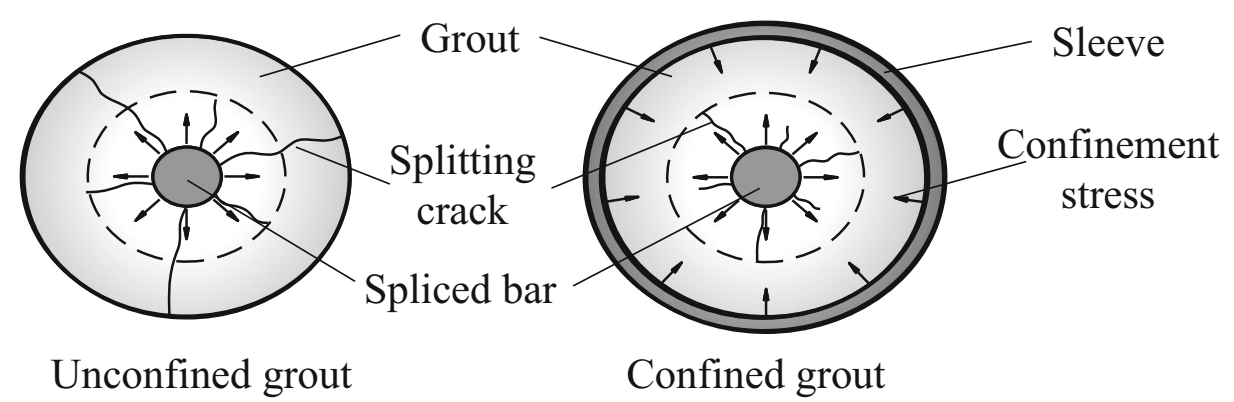

Fig. 2 Sleeve confines the grout and control the propagation of splitting cracks.

addition, the sleeve bridges the discontinuity of the spliced bars so that stress can be effectively transferred from one bar to another.

This technique of confining the bond region was an extreme condition of the regional confinement using the transverse reinforcements. It allows the stresses to be fully transferred at a shorter anchorage length of the bars as compared with the conventional bar lapping system. The required length ranges from 8.5 to 16 times the bar diameter $\left(8.5-16 d_{b}\right)$ (Haber et al. 2015).

The grouted splice sleeve can be used as the connection for precast concrete structures. It is embedded in the precast concrete elements during fabrications in the factories. At the construction site, steel bars extruding from the other precast element are inserted into the sleeve to form a connection (Fig. 3). Due to the enhanced bond performance, the extruding bars from the precast elements are kept minimal. Thus, the handling and installation of the elements are easier and this speeds up the construction project.

Grouted splice sleeves have been the proprietary products (Haber et al. 2015; Jansson 2008; Lin and Wu 2016) owned by several international companies. Designing the sleeves have been the works of specialists. In 1995, Einea et al. (Einea et al. 1995) proposed to connect steel bars with modified steel pipes. Researchers then realised that with adequate understanding of the load resisting mechanism, the materials that are commonly available at the construction site could easily be transformed into the grouted splice sleeves.

Since then, various materials and shapes have been proposed as the connection for steel bars. This includes mild steel pipes (Henin and Morcous 2015; Abd. Rahman et al. 2010; Ling et al. 2012; Alias et al. 2014; Alias et al. 2013), high strength steel (Seo et al. 2016), aluminum tubes (Ling et al. 2008; Tullini and Minghini 2016), spirals (Aldin Hosseini and Abd. Rahman 2013; Aldin Hosseini and Abd. Rahman 2016; Aldin Hosseini et al. 2015; Sayadi et al. 2014; Hosseini and Rahman 2013), square hollow sections (Ling et al. 2014) and glass fiber reinforced polymers (Sayadi et al. 2015; Koushfar et al. 2014; Tastani 2002; Tibbetts et al. 2009).

These connections differ from one another in terms of (a) the mechanical properties of materials used and (b) the load resisting mechanisms as a result of the sleeve configurations and designs. Therefore, the response of connection

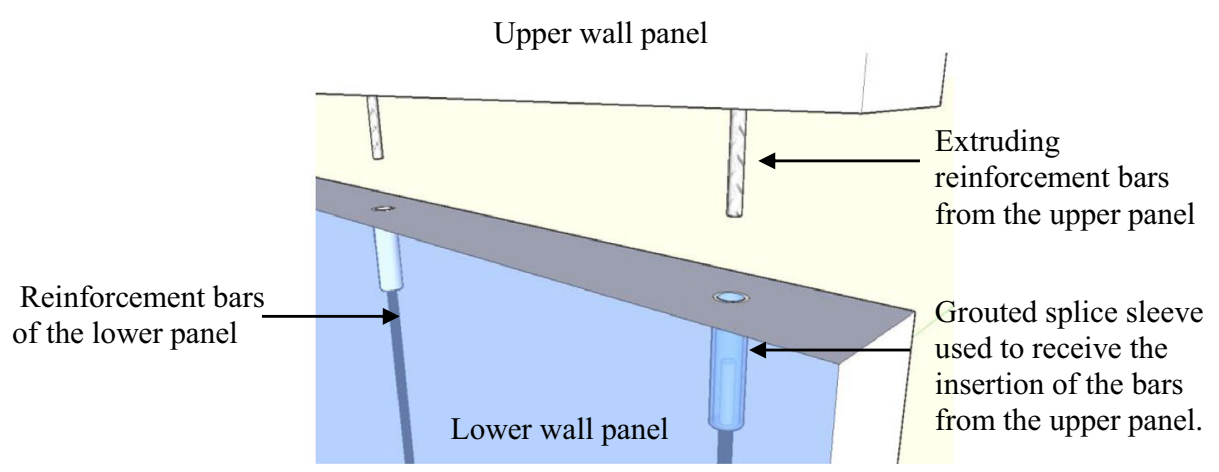

Fig. 3 Grouted splice sleeve as the connection of precast concrete wall panels (Loh 2008). 
under load, the required anchorage length of the bars and the amount of materials required vary slightly among each other.

Nevertheless, these connections have the following in common:

a. The sleeve needs to resist the tensile load and confine the bond at the same time. Both the longitudinal and lateral deformations are detected under tensile load.

b. The mechanical interlocking among the grout, the spliced bar and the sleeve are equally important. The bond slip failure could occur at the bar or at the sleeve.

These connections might not be as effective as the proprietary products in terms of having a minimum anchorage length, but they are advantageous in the following aspects:

a. The materials used are easily accessible on any construction site.

b. The connection can be fabricated on site by using simple techniques such as welding and cutting.

c. The connection can be modified to suit the needs on site, such as the allowable tolerance and anchorage length.

Grouted splice sleeves are usually tested with a tensile load to determine the feasibility and the characteristic strength. The test is simple, cheap and easy to handle. The relevant standards specify a minimum tensile capacity of $125 \%$ of the nominal yield strength of the spliced bars (ACI318 2002; AC-133 2008). A good grouted splice connection generally offers a stiffness about equivalent to a steel bar and undergoes the stages of elastic, yielding and plastic responses when subjected to incremental tensile load (Ling et al. 2012). The design capacity is recommended to be not higher than the yielding strength.

However, the tensile test alone is insufficient to determine the actual behaviour and performance of the grouted splice connection in precast concrete structures. The loads acting on the connection might not always be in tension. There could be other forces acting on the connection. Hence, experimental studies were conducted on the precast concrete frames with the connections of beam-to-beam (Aldin Hosseini et al. 2015; Sayadi et al. 2014), column-to-beam (Ameli et al. 2015; Kim 2000), column-to-column (Tullini and Minghini 2016), wall-to-wall (Soudki et al. 1995; Zhu and Guo 2016) and column-to-foundation (Haber et al. 2014; Belleri and Riva 2012) to determine the structural performance.

This study transforms steel pipe sections into grouted splice sleeves by simply welding some steel bars on it. These sleeves are used to connect the precast concrete walls (Fig. 3). It is to determine if these non-proprietary sleeves can be used as the connection for walls.

Depending on the locations installed, the connections are subjected to tensile, shear and flexural loads when the wall frame system is subjected to lateral load (Fig. 4). To determine the behaviour and the feasibility of the connections, an experimental study was conducted. The aim was to acquire the responses of the connection under different load cases.

\section{Experimental Program}

\subsection{Test Specimens}

Welded Bar Sleeve (WBS) was made from mild steel pipes (nominal yield strength, $f_{s y}=250 \mathrm{~N} / \mathrm{mm}^{2}$ ) with the inner diameters, $d_{s i}$, of 50,65 and $75 \mathrm{~mm}$. Four steel bars $\left(f_{s y}=500 \mathrm{~N} / \mathrm{mm}^{2}\right.$ and $\left.d_{w b}=10 \mathrm{~mm}\right)$ were welded to the inner surface of the pipe at the ends (Fig. 5). These bars provide an interlocking mechanism for the grout to bond with spliced bars. Then, steel bars $\left(f_{s y}=500 \mathrm{~N} / \mathrm{mm}^{2}\right.$ and bar diameter, $d_{b}$, of $16 \mathrm{~mm}$ ) were spliced at the embedded lengths, $l_{b}$, of 75, 125 and $175 \mathrm{~mm}$ (Fig. 5; Table 1).

Non-shrink grout (Sika Grout-215), with a nominal strength of $70 \mathrm{~N} / \mathrm{mm}^{2}$ at day 28 , was mixed into a pour-able state based on the proportions recommended by the manufacturer (4 litres of water: $25 \mathrm{~kg}$ of grout). The grout was poured into the sleeve prior to insertion of the steel bar.

\subsection{Test Programs \\ 2.2.1 Tensile Test}

Nine sets of specimens with different configurations were tested with $0.5 \mathrm{kN} / \mathrm{s}$ incremental tensile load (Table 1). Each set consists of three identical specimens; thus, a total of 27 specimens were tested with the tensile load (Table 2).

The displacements were measured by using the built-in linear variable differential transducers (LVDT) of the hydraulic actuator (Fig. 6). Three strain gauges (SG) were installed on each specimen (Fig. 6);

i. SG1 was installed on the spliced bar at about one bar diameter from the surface of the grout. It was used to measure the elongation of the bar (ASTM 2005);

ii. SG2 was installed transversely on the sleeve at the mid length of the bar embedded length. It was used to measure the lateral deformations of the sleeve due to splitting expansion of the grout in the sleeve (Einea et al. 1995; Henin and Morcous 2015);

iii. SG3 was installed longitudinally at the mid length of the sleeve. It was used to measure the longitudinal elongation of the sleeve.

\subsubsection{Shear and Flexural Tests}

For the shear and flexural tests, six specimens were tested each. This included a control and five wall assembly specimens (Table 2).

Each specimen comprised two precast concrete panels as illustrated in Fig. 7. The dimensions of the panels are given in Table 3. Two sleeves were embedded in the lower panel and two steel bars are extruded from the upper panel. During installation, the steel bars were inserted into the sleeve and bonded by the grout in the sleeve. A layer of $25 \mathrm{~mm}$ mortar dry pack was laid between the two panels.

For the control specimens, the reinforcement bars were continuous and embedded in the wall panels with a full anchorage length. The dimensions were same as the other specimens, as specified in Table 3. 

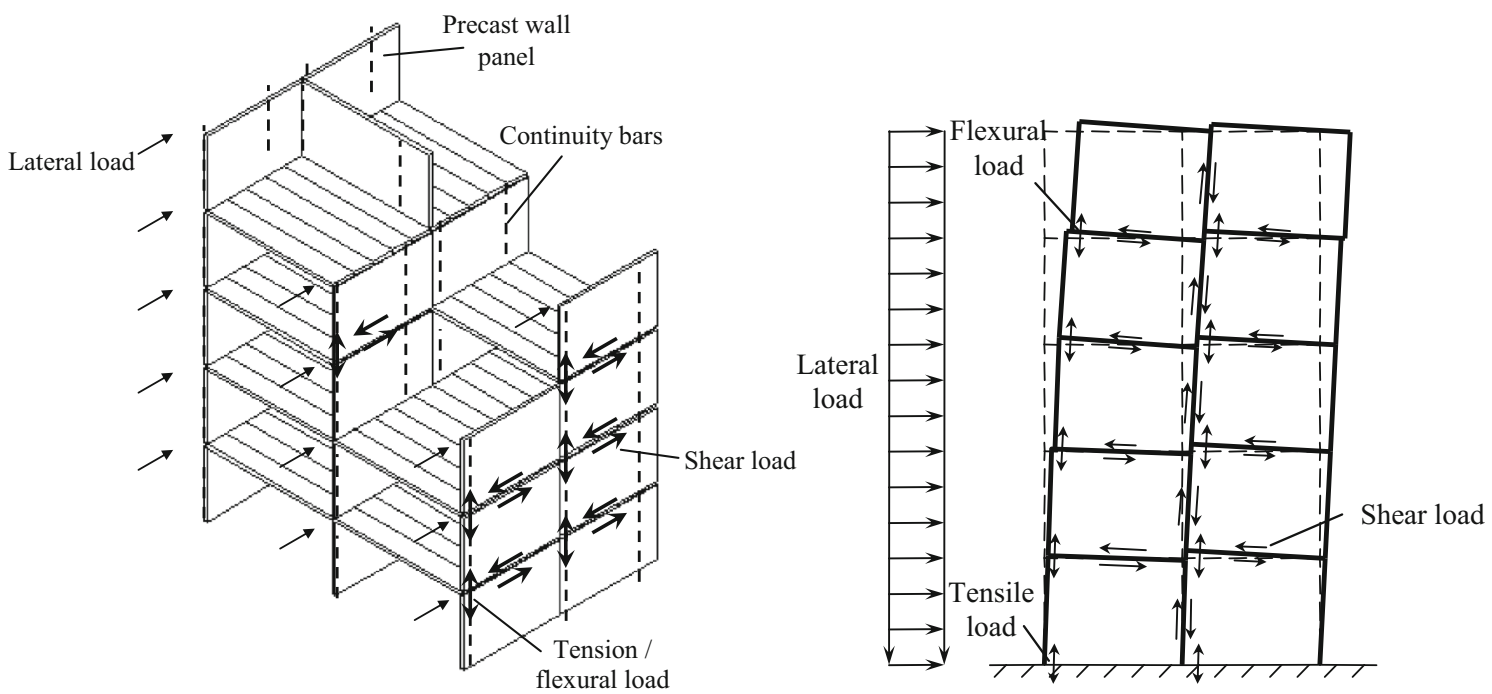

Fig. 4 Tensile, shear and flexural loads acting on the grouted splice connection of a precast concrete wall frame system as a result of the lateral load (Ling 2011).

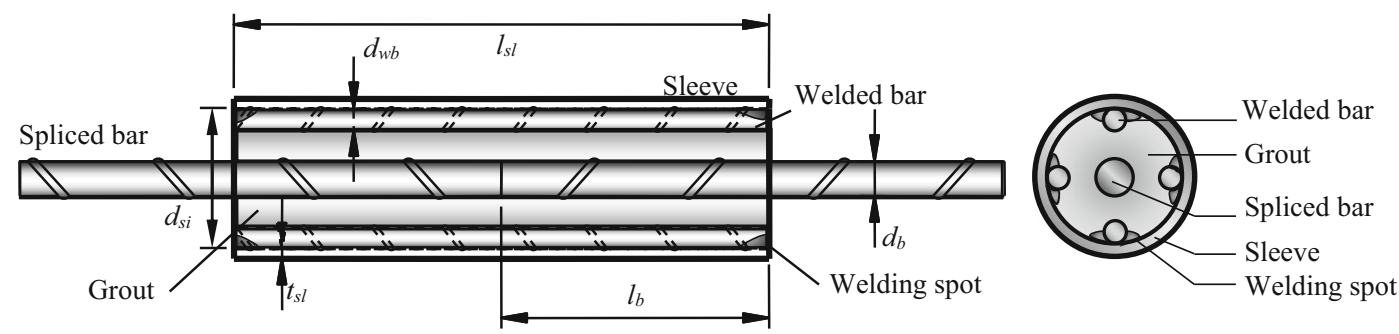

Fig. 5 Schematic design of Welded Bar Sleeve (WBS).

Table 1 The dimensions of Welded Bar Sleeve (WBS).

\begin{tabular}{|c|c|c|c|c|c|c|}
\hline \multirow[t]{2}{*}{ Specimen } & \multicolumn{2}{|c|}{ Spliced bar } & \multicolumn{4}{|c|}{ Sleeve } \\
\hline & $d_{b}(\mathrm{~mm})$ & $l_{b}(\mathrm{~mm})$ & $d_{s i}(\mathrm{~mm})$ & $l_{s l}(\mathrm{~mm})$ & $t_{s l}(\mathrm{~mm})$ & $d_{w b}(\mathrm{~mm})$ \\
\hline WBS-1 & \multirow[t]{9}{*}{16} & \multirow[t]{3}{*}{75} & 50 & \multirow[t]{3}{*}{150} & \multirow[t]{9}{*}{4.5} & \multirow[t]{9}{*}{10} \\
\hline WBS-2 & & & 65 & & & \\
\hline WBS-3 & & & 75 & & & \\
\hline WBS-4 & & \multirow[t]{3}{*}{125} & 50 & \multirow[t]{3}{*}{250} & & \\
\hline WBS-5 & & & 65 & & & \\
\hline WBS-6 & & & 75 & & & \\
\hline WBS-7 & & \multirow[t]{3}{*}{175} & 50 & \multirow[t]{3}{*}{350} & & \\
\hline WBS-8 & & & 65 & & & \\
\hline WBS-9 & & & 75 & & & \\
\hline
\end{tabular}

The displacement of the panels was measured by a series of LVDTs illustrated in Fig. $7, H_{1}$ to $H_{10}$. Strain gauges were installed along Bar 1 of each specimen. Strain gauges SG1 to SG3 were installed at the same positions as the tensile test. SG4 and SG5 were installed on the spliced bars at a distance of $200 \mathrm{~mm}$ intervals.

The incremental lateral load was imposed by the hydraulic jack (Brand: Enerpac, Capacity: $500 \mathrm{kN}$ ) at the dry pack joint and at $1800 \mathrm{~mm}$ height from the joint for shear and flexural tests, respectively. The experiment started with a load-controlled mode where readings were taken at every 10 $\mathrm{kN}$ load increment. Then, as the specimen yielded and a large displacement was detected, the displacement-controlled mode was used. Readings were taken at every $2 \mathrm{~mm}$ displacement. This was in order to obtain a smooth loaddisplacement curve. 
Table 2 Number of specimens tested for each load case.

\begin{tabular}{c|c|c|c}
\hline \multirow{2}{*}{ Specimens } & \multicolumn{2}{|c}{ Nos. of specimen } & Flexural test \\
\cline { 2 - 4 } & Tensile test & Shear test & 1 \\
\hline \hline Control & 3 & 0 & 0 \\
\hline WBS-1 & 3 & 1 & 1 \\
\hline WBS-2 & 3 & 0 & 1 \\
\hline WBS-3 & 3 & 1 & 1 \\
\hline WBS-4 & 3 & 1 & 1 \\
\hline WBS-5 & 3 & 0 & 0 \\
\hline WBS-7 & 3 & 1 & 1 \\
\hline WBS-8 & 3 & 0 & 0 \\
\hline
\end{tabular}

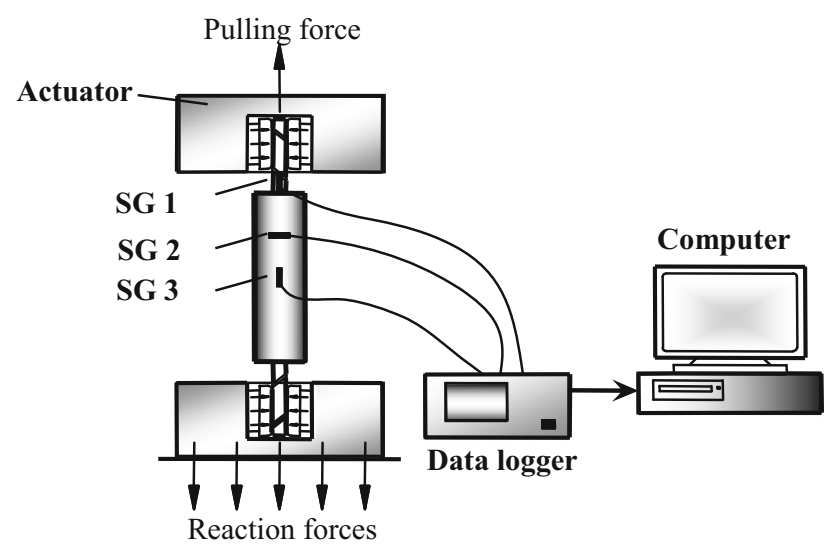

Fig. 6 Instrumental setup for tensile test.

While conducting the experiment, the yielding of the specimen was detected when the real-time load-displacement response was no longer linear, and a large displacement was detected with respect to a small load increment.

The tests were conducted as per the standard procedures recommended by ASTM E564 (E564-06 2006). Prior to commencement of the test, all instrumentation readings were initiated to zero. A preload of about $10 \%$ of the estimated ultimate load was applied and held for $5 \mathrm{~min}$ to seat all the connections. The pre-load was removed for another $5 \mathrm{~min}$ before all the gauge readings were read as the initial readings.

The incremental load was applied in three cycles at $10 \mathrm{kN}$ load interval. The load was maintained for at least $1 \mathrm{~min}$ before each reading was taken. As the load achieved $1 / 3$ and $2 / 3$ of the estimated ultimate load (which are 100 and 200 $\mathrm{kN}$ for shear load, and 20 and $40 \mathrm{kN}$ for flexural load) the applied load was released at the same rate. As the load was fully removed, the recovery of the specimen was recorded after $5 \mathrm{~min}$. The connection was tested to fail in the third cycle.

\section{Results and Analysis}

\subsection{Load Capacities}

Table 4 shows the compressive strengths of the grout, concrete and mortar dry pack on the day that the specimens were tested. The ultimate capacity, displacement and failure mode of each specimen are shown in Table 5.

The specimens generally failed in two modes, namely bar fracture and bond-slip failures. The bar fracture failure is preferred as it indicates that the grouted splice could generate a higher bond strength than the tensile strength of the spliced bars. Based on the results, the spliced bars generally fractured at about 128, 297 and $82 \mathrm{kN}$ for tensile, shear and flexural loads, respectively.

For this, the specimens offering a higher capacity than these values are considered to be adequate. The adequate specimens are: (a) WBS-4, 5, 7, 8 and 9 for tensile test; (b) WBS-5, 6 and 8 for shear test, and (c) WBS-5 and 8 for flexural test.

For this, the following is found (Table 5):

a. The embedded length of $125 \mathrm{~mm}\left(\approx 8 d_{b}\right)$ is adequate for resisting tensile load.

b. The embedded length of $125 \mathrm{~mm}\left(\approx 8 d_{b}\right)$ is adequate for WBS to withstand shear load, regardless of the sleeve diameter. As the bar embedded length required to resist the shear load could be shorter than $125 \mathrm{~mm}$, and with the amount of data available, it is difficult to determine if the sleeve diameter affects the shear capacity of the connection.

c. To resist flexural load, $175 \mathrm{~mm}\left(\approx 11 d_{b}\right)$ bar embedded length is required.

Based on these findings, the followings can be concluded:

a. The loading capacity of the grouted splice connection increases as the bar embedded length increases in all load cases. 

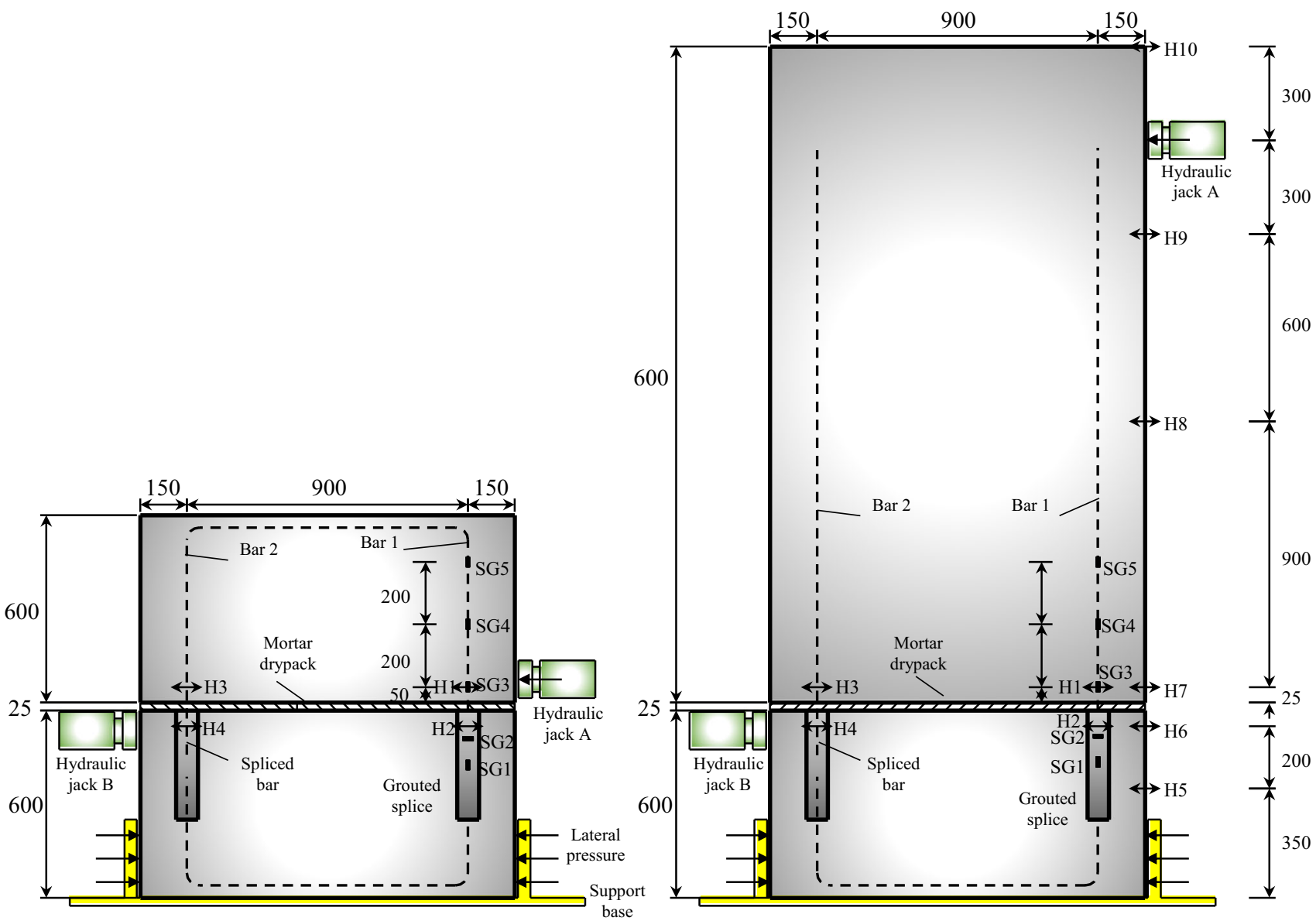

Fig. 7 Details and instrumentation of wall assembly specimen (unit: $\mathrm{mm}$ ).

Table 3 Size of wall panels for shear and flexural tests.

\begin{tabular}{|c|c|c|}
\hline & Shear test & Flexural test \\
\hline Position of lateral load & At just above the dry pack connection & $\begin{array}{l}\text { At } 100 \mathrm{~mm} \text { height above the dry pack } \\
\text { connection }\end{array}$ \\
\hline Thickness of panels & \multicolumn{2}{|c|}{$150 \mathrm{~mm}$} \\
\hline Size of lower panel & \multicolumn{2}{|c|}{$1200 \times 600 \mathrm{~mm}$} \\
\hline Size of upper panel & $1200 \times 600 \mathrm{~mm}$ & $1200 \times 1200 \mathrm{~mm}$ \\
\hline Thickness of dry pack & \multicolumn{2}{|c|}{$25 \mathrm{~mm}$} \\
\hline
\end{tabular}

b. The tensile capacity of the connection increases as the sleeve diameter decreases. The effect of sleeve diameter seems to be insignificant when the connection is subjected to shear and flexural loads.

Theoretically, small sleeve diameter is beneficial to the capacity of the connection. This can be observed from the test results obtained from tensile test and the previous studies. A smaller sleeve diameter offers a more effective confinement to improve the bond performance in the sleeve (Ling et al. 2012). However, it is noted that a smaller sleeve diameter might lead to the following problems:

a. Inadequate tolerance for installation of the grouted splice connection during erection of the precast wall panels. As a result, the dimension of the precast panels and the position of the steel bars and the sleeve need to be fabricated at a higher level of precision. The recommended tolerance is about $25 \mathrm{~mm}$ as stated in ACI-117 (ACI-117 1990).

b. Inadequate opening size for the filling of the grout in the sleeve. This is reflected by the poor capacity offered by specimen WBS-4 tested under shear and flexural loads. For this, much effort is required to ensure the spliced bars are fully anchored in the sleeve.

\subsection{Behaviour of Grouted Splice Connection 3.2.1 Response Under Tensile Load}

Tensile load caused the entire grouted splice specimens to deform and elongate longitudinally. The deformation of the sleeve was insignificant compared with the spliced bars. A large deformation of the connection was noticed as the 
Table 4 Compressive strength of concrete, mortar and grout for each specimen (unit: N/mm²).

\begin{tabular}{|c|c|c|c|c|c|c|c|}
\hline \multirow[t]{2}{*}{ Specimen } & \multirow{2}{*}{$\begin{array}{c}\text { Tensile test } \\
\text { Compressive } \\
\text { strength of } \\
\text { grout, } f_{u, g}\end{array}$} & \multicolumn{3}{|c|}{ Shear test } & \multicolumn{3}{|c|}{ Flexural test } \\
\hline & & $\begin{array}{l}\text { Compressive } \\
\text { strength of } \\
\text { concrete, } f_{u, c}\end{array}$ & $\begin{array}{l}\text { Compressive } \\
\text { strength of } \\
\text { mortar, } f_{u, m} \\
\end{array}$ & $\begin{array}{l}\text { Compressive } \\
\text { strength of } \\
\text { grout, } f_{u, g} \\
\end{array}$ & $\begin{array}{l}\text { Compressive } \\
\text { strength of } \\
\text { concrete, } f_{u, c}\end{array}$ & $\begin{array}{l}\text { Compressive } \\
\text { strength of } \\
\text { mortar, } f_{u, m} \\
\end{array}$ & $\begin{array}{c}\text { Compressive } \\
\text { strength of } \\
\text { grout, } f_{u, g} \\
\end{array}$ \\
\hline Control & & 43.2 & 20.0 & 67.9 & 59.6 & 21.4 & 73.1 \\
\hline WBS-1 & \multirow[t]{9}{*}{76.8} & & & & & & \\
\hline WBS-2 & & 45.0 & 28.6 & 63.8 & 64.4 & 18.0 & 88.1 \\
\hline WBS-3 & & & & & & & \\
\hline WBS-4 & & 44.9 & 18.5 & 68.2 & 66.9 & 30.7 & 73.4 \\
\hline WBS-5 & & 43.4 & 20.3 & 83.7 & 64.4 & 26.7 & 72.6 \\
\hline WBS-6 & & 43.6 & 16.3 & 83.3 & 67.9 & 19.5 & 85.0 \\
\hline WBS-7 & & & & & & & \\
\hline WBS-8 & & 45.6 & 19.0 & 81.6 & 61.0 & 30.8 & 69.3 \\
\hline WBS-9 & & & & & & & \\
\hline
\end{tabular}

spliced bars yielded. The specimens eventually failed either by bar fracture or bond-slip failures.

Two types of load-displacement responses were observed (Fig. 8). The connections with adequate bond strength exhibited ductility characteristics prior to failure (Fig. 8a), while inadequate bond strength endured a brittle failure (Fig. 8b).

Specimens WBS-4, 5, 7, 8 and 9 behaved elastically with a high degree of stiffness at the initial stage, as demonstrated by the steep gradient of the load-displacement curve in Fig. 8a (line A-B). The sleeve and the spliced bars elongated slowly and proportional to the load increments. As the bars yielded at approximately $110 \mathrm{kN}$ load, they elongated rapidly and behaved plastically. As a result, the stiffness of the connection decreased drastically. These specimens reached the ultimate states at about $130 \mathrm{kN}$ with a large displacement of about $30 \mathrm{~mm}$.

Figure $8 \mathrm{~b}$ shows the response of the grouted splice connection when inadequate bond strength was generated in the sleeve (WBS-1, 2, 3 and 6). These connections generally failed with bars slipping out of the sleeves at a low ductility. They behaved elastically with a high degree of stiffness until the bond between the bar and the grout failed suddenly at a load less than $110 \mathrm{kN}$.

\subsubsection{Response Under Shear Load}

The shear load caused the upper panel to displace horizontally and slide on the dry pack. The lower panel remained stationary while the bar deformed significantly and failed by bar fracture or bond-slip failure. Cracks were found to occur at the cold joints between the dry pack and the panels.

Figure 9 shows a typical load-displacement response of the wall assembly specimens when subjected to an incremental shear load. It underwent the stages of (a) pre-crack, (b) bar dowel action, (c) post dowel action and (d) ultimate failure.

The pre-crack stage was a state without any crack on the wall specimen (curve A-B). The specimen resisted the incremental shear load with good integrity. The upper panel displaced slowly and a high degree of stiffness was developed with respect to the load increment.

The first crack occurred at the dry pack joint at about 100 $\mathrm{kN}$. The steel bars joining the two panels started undergoing the bar dowel action. This occurred in two stages, namely bar bending and kinking actions (West et al. 1993; Soudki 1994).

During the bar bending action, both Bars 1 and 2 hinged at two points near the joints between the dry pack and the wall panels (Fig. 10). The upper wall panel displaced horizontally in a rapid manner due to low shear resistance generated during the bar hinging process (curve B-C in Fig. 9). Thus, a low degree of stiffness was developed.

The incremental shear load was applied in three cycles. A negligible permanent displacement was detected after the first load cycle before the bar dowel action took place. After the second load cycle, a large permanent displacement was detected (Fig. 11a). The deformation was due to the bar bending and kinking actions, and it was permanent and irreversible.

The results show a good continuity of load-displacement response between the load cycles (Fig. 11b). The load-displacement response followed the path of the previous load cycle and continued thereafter.

All specimens failed when Bar 1 fractured except WBS-2. These two specimens failed as the bar slipped out of the sleeve during the bar dowel action.

The responses of both Bars 1 and 2 were similar (Fig. 11). Bar 1 was located closer to the shear load. It generally gave 


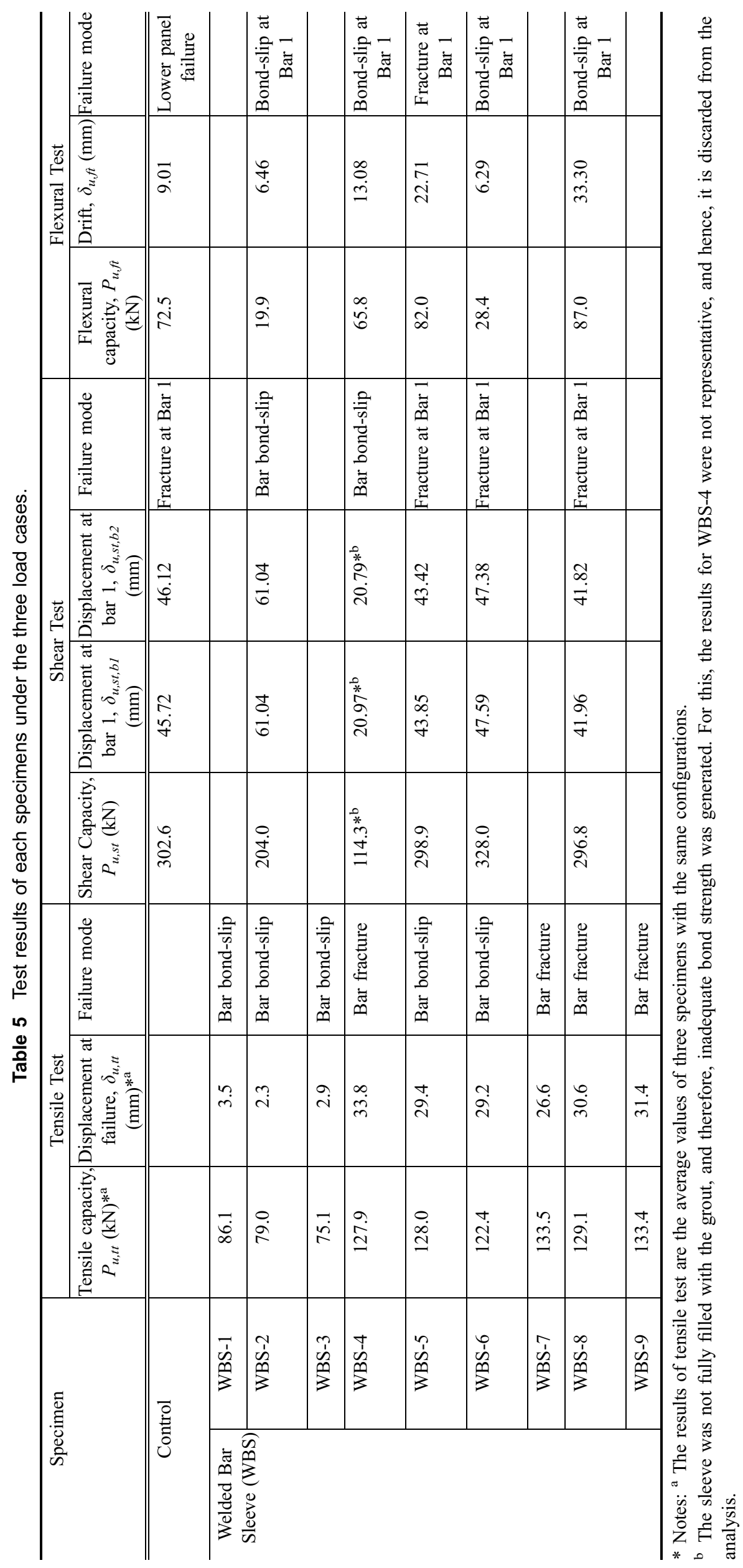




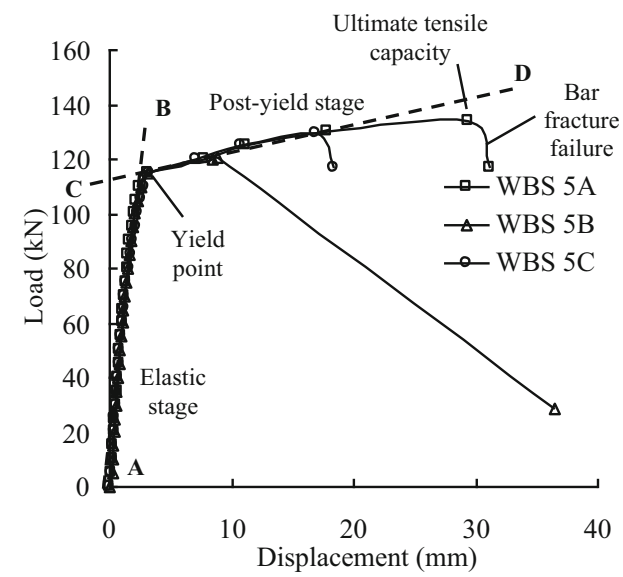

(a) Ductile response (specimen WBS-5)

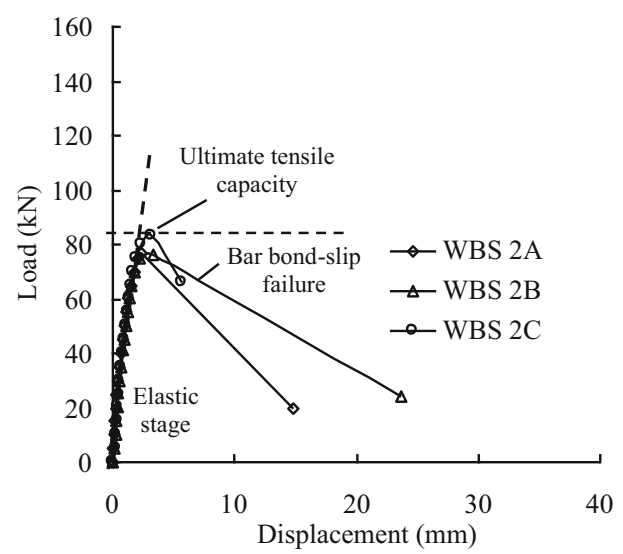

(b) Brittle response (specimen WBS-2)

Fig. 8 Load-displacement response under tensile load

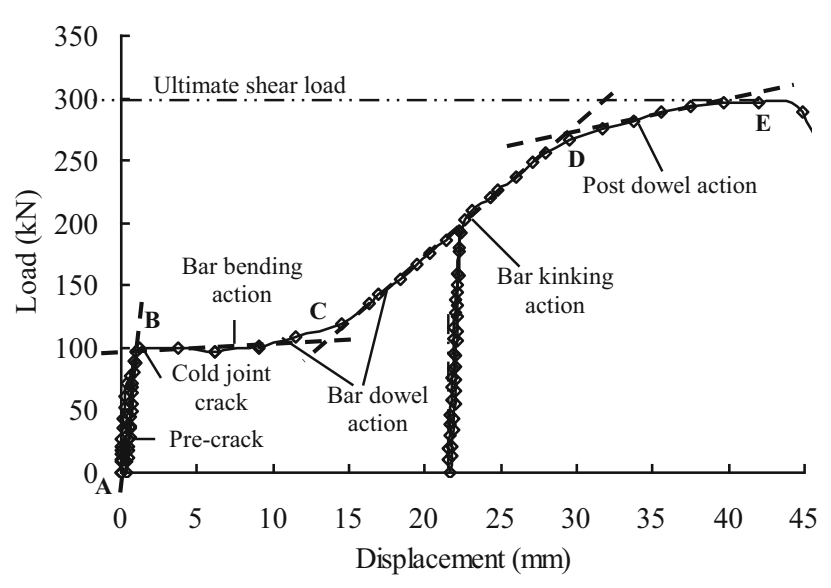

Fig. 9 Load-displacement response of wall assembly under shear load (specimen WBS-8).

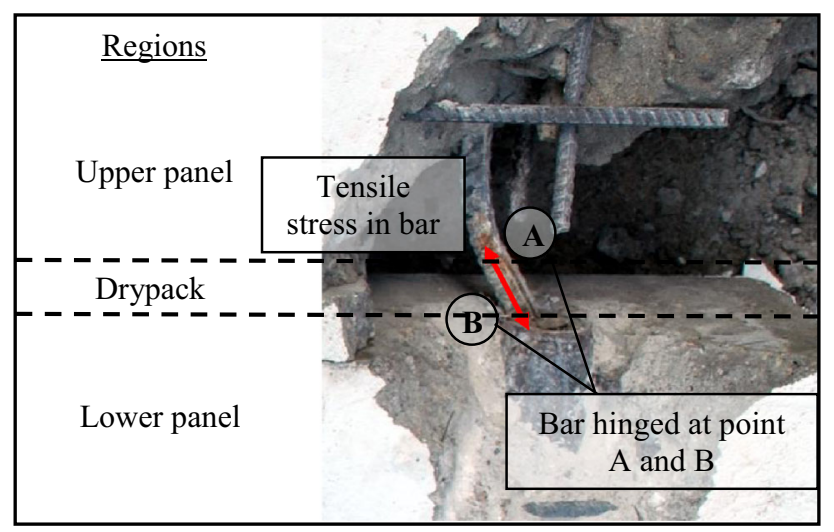

Fig. 10 The deformation of the bars after bar dowel action (specimen WBS-8).

not more than $1 \mathrm{~mm}$ larger displacement compared with Bar 2. This explains why the specimens always failed at Bar 1 .

\subsubsection{Response Under Flexural Load}

The lateral load applied at $1800 \mathrm{~mm}$ height from the dry pack caused a rotational movement of the upper panel. Bar 1 was in tension while Bar 2 was in compression. The upper panel rotated and drifted until Bar 1 fractured or slipped out of the sleeve.

Figure 12 demonstrates two typical load-drift responses of the specimens when subjected to an incremental flexural load. When the bond strength was adequate, the specimens exhibited a ductile behaviour prior to failure (Fig. 12a). Otherwise, the specimens failed in a brittle manner (Fig. 12b).

Specimens WBS-2, 4, 6 failed at 19.9, 65.8 and $28.4 \mathrm{kN}$ flexural load, respectively, and gave a low ductility response. These specimens initiated with a high degree of stiffness, but failed suddenly as Bar 1 slipped out of the sleeve. This was due to inadequate bar embedded length and insufficient bond strength generated in the sleeves.

Specimens WBS-5 and 8 offered the load capacity of 82 and $87 \mathrm{kN}$, respectively. These specimens demonstrated ductile responses where the upper panels drifted for at least $22 \mathrm{~mm}$ before failure.

The yield strength of the spliced bars was not achieved during the first two load cycles. The upper panel managed to recover to its original position with a minor permanent drift of less than $3 \mathrm{~mm}$. As the load exceeded the yield strength of about $60 \mathrm{kN}$ load, drift developed rapidly and the stiffness decreased dramatically.

It was noticed that most of the specimens experienced an initial drift of 2-3 mm immediately after the flexural load was applied, as demonstrated in Fig. 12b. The cause of this phenomenon is uncertain. This could be due to the sudden settlement of the connection as the dry pack around Bar 2 was undergoing the compressive deformation (Fig. 13).

\subsubsection{Response of Internal Stresses under Different Load Cases}

Figure 14 illustrates the internal stresses generated in WBS under tensile, shear and flexural loads. The ribs on the spliced bars and the welded bars interlock with the grout in the sleeve. This generates a resultant stress acting perpendicularly to the surface of the rib. The resultant stress can be derived into two components, namely the normal and longitudinal stress (Abd. Rahman et al. 2010). 


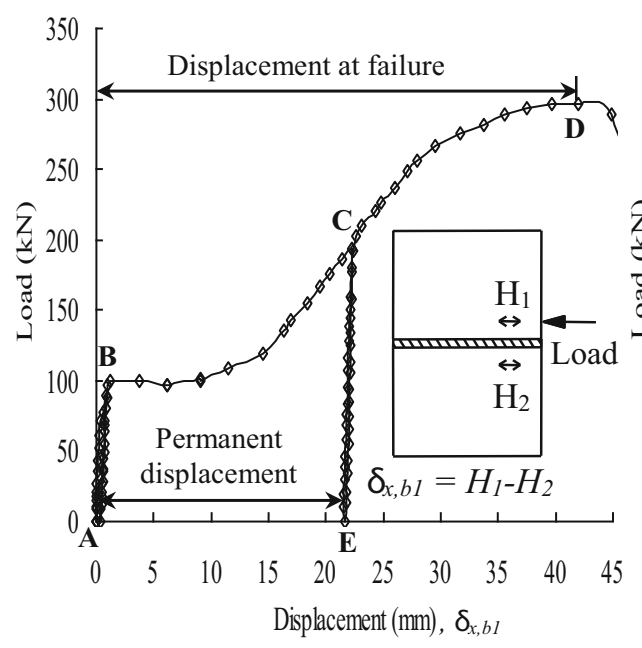

i. Bar 1

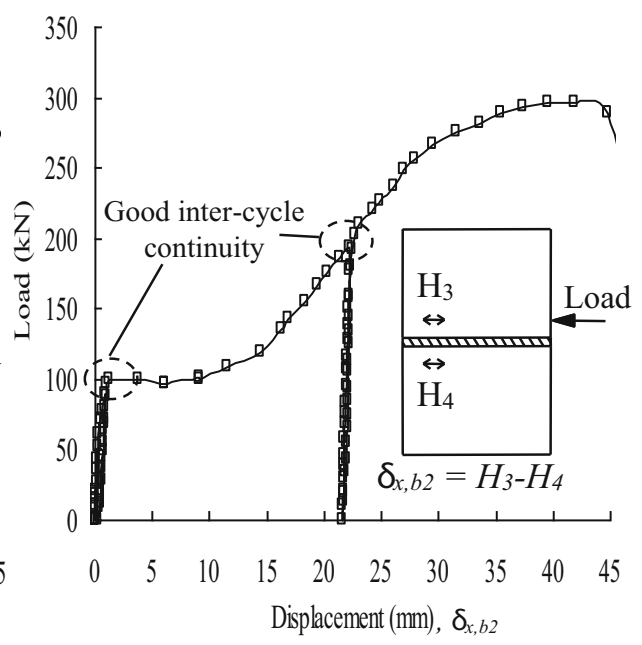

ii. Bar 2

Fig. 11 Comparison of load-displacement for bars 1 and 2 (Specimen WBS).

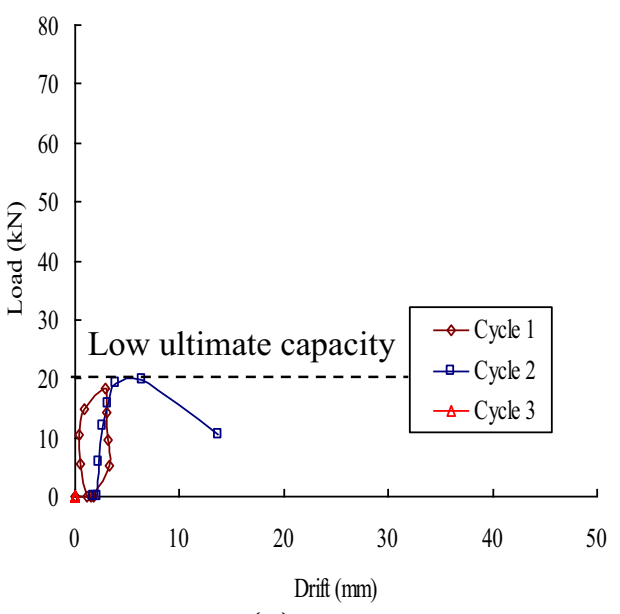

(a) WBS-2

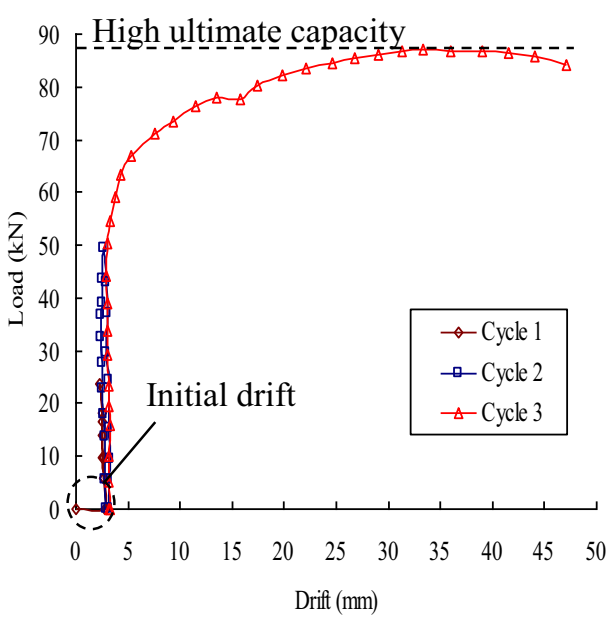

(b) WBS-8

Fig. 12 Load-drift response of wall assembly specimen under flexural load.

The longitudinal stress acting on the spliced bar prevents it from slipping out of the sleeve. However, the normal stress generates splitting cracks surrounding it, and this may degrade the bond performance between the grout and the spliced bar.

As for the welded bar, the longitudinal stress prevents the grout from slipping out of the sleeve, while the normal stress generates confinement stress to control the propagation of the splitting cracks. The transverse tensile stress in the sleeve also provides confinement to the grout and controls the propagation of splitting cracks. These confinement stresses are beneficial in maintaining good bond performance in the sleeve.

The internal stress in WBS is believed to vary slightly with different load cases (Table 6; Fig. 14). The magnitude of the normal and confinement stresses should be same in all directions when WBS is subjected to tensile load. Under shear load, a higher stress concentrates on the region that is in contact with it. As the componential shear load is less dominant in flexural load, the difference between the maximum and minimum stresses in the sleeve is less significant than when subjected to the shear load (Fig. 14).

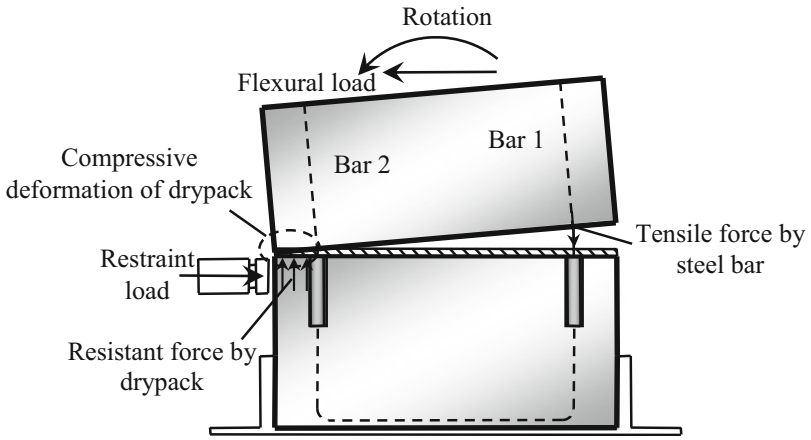

Fig. 13 Contribution of compressive deformation of dry pack to the rotation of the upper panel.

\section{Feasibility Evaluation of Grouted Splice Connection}

The feasibility of the grouted splice connections for each load case is evaluated in terms of ultimate capacities, displacement, serviceability and failure mode. The ultimate 


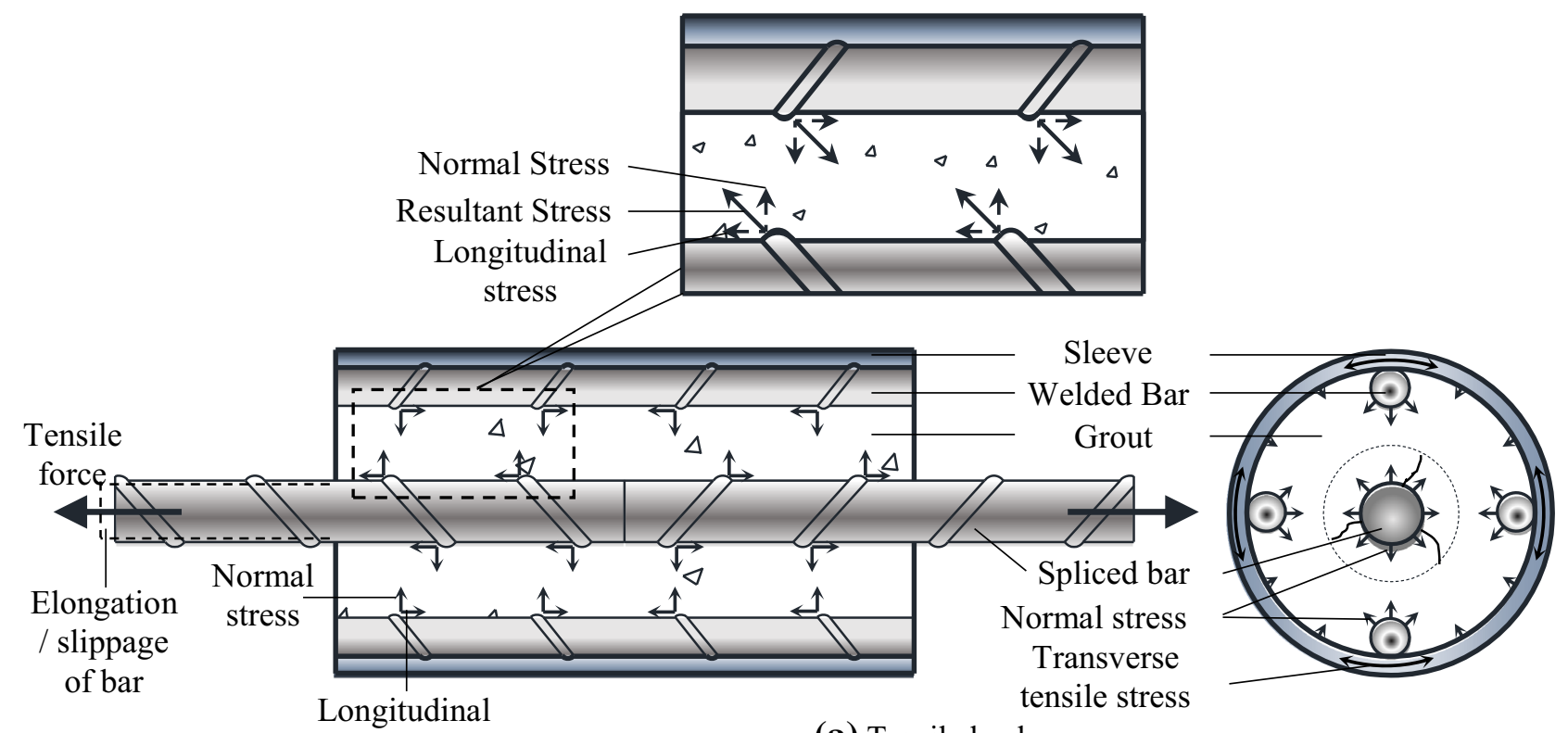

stress

(a) Tensile load
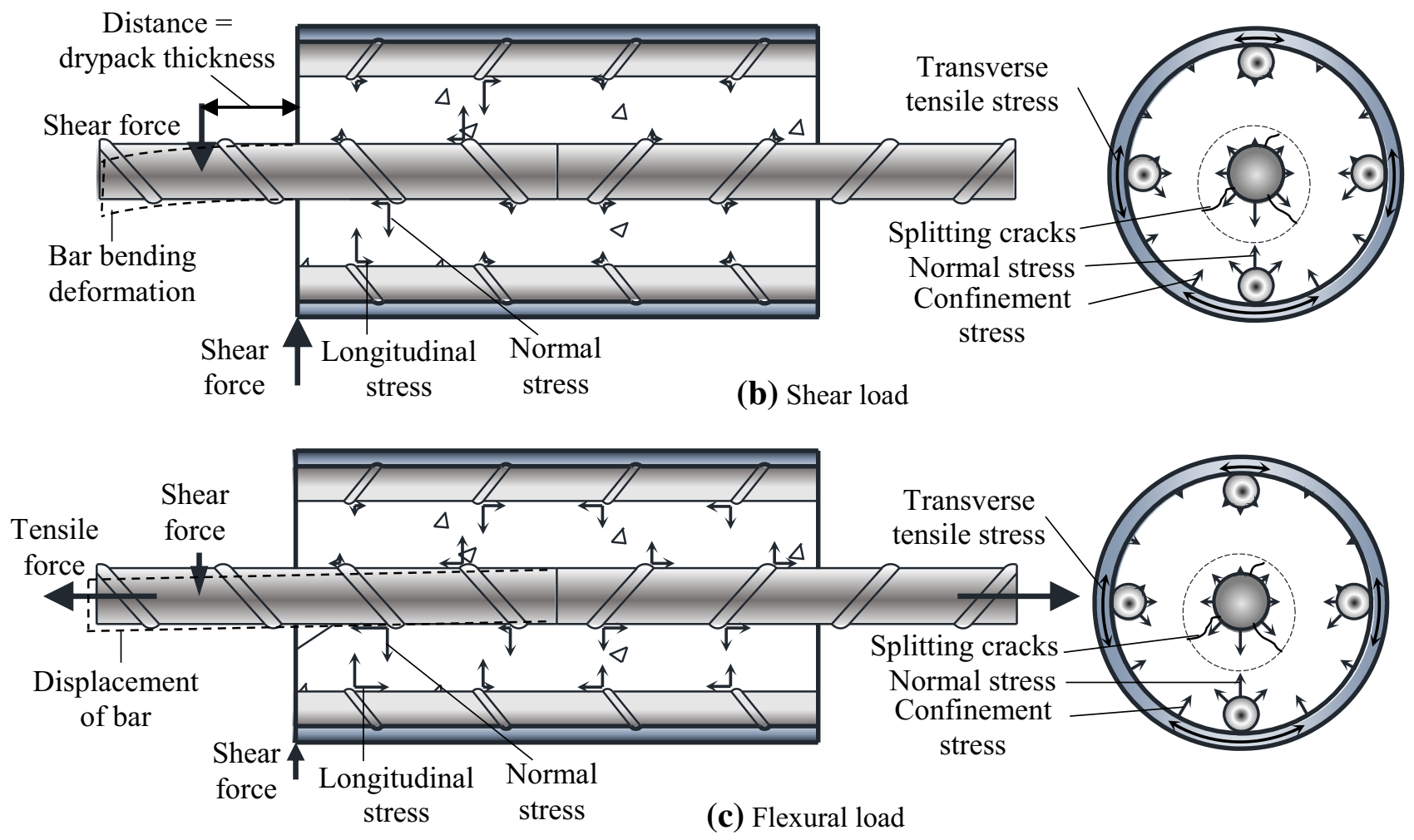

Fig. 14 The internal stress in WBS varies slightly under different load cases.

capacity represents the ability of the connection to resist load; the displacement represents the ductility response; the serviceability indicates the usable capacity out of the total capacity available for the design purpose, and the failure modes imply the causes of failure.

The assessment criteria for determining the feasibility of the connection are:

a. C1: Tensile capacity of at least $125 \%$ of the specified yield strength of the spliced bars (ACI-318, 2002; AC133 2008).
Hence, the strength ratio, $R_{s}$, should be at least 1.25 (Eq. 1). $R_{s}$ is computed by dividing the ultimate bar stress, $f_{u, b}$, with its specified yield strength, $f_{s y}$ (Eq. 1). It indicates the degree of additional strength generated by the grouted splice relative to the design strength of the connection.

$$
R_{\mathrm{s}}=\frac{f_{u, b}}{f_{s y}}
$$

b. C2: The connection fails in a ductile manner for survival purpose (ACI-318 2002; BS8110-1:1997 1997).

The relevant indicators include the yield, ductility and drift ratios: 
Table 6 Comparison of the response of WBS under different load case.

\begin{tabular}{|c|c|c|c|}
\hline Response & Tensile load & Shear load & Flexural load \\
\hline \multirow[t]{2}{*}{ Stresses acting on the spliced bar } & $\begin{array}{c}\text { The normal stress is similar in all } \\
\text { directions }\end{array}$ & $\begin{array}{l}\text { The normal stress in the region } \\
\text { directly in contact with the shear } \\
\text { force is higher than the other } \\
\text { region }\end{array}$ & $\begin{array}{c}\text { The region directly in contact with } \\
\text { the shear force has a slightly } \\
\text { higher stress compared with the } \\
\text { other region }\end{array}$ \\
\hline & $\begin{array}{l}\text { A high longitudinal stress is } \\
\text { generated to prevent the spliced } \\
\text { bars from slipping out of the } \\
\text { sleeve }\end{array}$ & $\begin{array}{c}\text { The longitudinal stress is at } \\
\text { minimal because the pullout force } \\
\text { is less likely to occur }\end{array}$ & $\begin{array}{l}\text { A high longitudinal stress is } \\
\text { generated in the region directly in } \\
\text { contact with the componential } \\
\text { shear force to prevent the spliced } \\
\text { bars from slipping out of the } \\
\text { sleeve }\end{array}$ \\
\hline \multirow[t]{2}{*}{ Stressed acting on the welded bar } & $\begin{array}{c}\text { The normal stress is similar in all } \\
\text { directions }\end{array}$ & $\begin{array}{c}\text { The welded bar in the direction of } \\
\text { the shear load has a higher } \\
\text { normal stress compared with the } \\
\text { others }\end{array}$ & $\begin{array}{c}\text { The welded bar in the direction of } \\
\text { the componential shear load has a } \\
\text { slight higher normal stress } \\
\text { compared with the others }\end{array}$ \\
\hline & $\begin{array}{l}\text { A high longitudinal stress is } \\
\text { generated to prevent the grout } \\
\text { from slipping out of the sleeve }\end{array}$ & $\begin{array}{c}\text { The longitudinal stress is at } \\
\text { minimal because the pullout force } \\
\text { acting on the grout is less likely } \\
\text { to occur }\end{array}$ & $\begin{array}{l}\text { A high longitudinal stress is } \\
\text { generated to prevent the grout } \\
\text { from slipping out of the sleeve }\end{array}$ \\
\hline \multirow[t]{2}{*}{ Pipe sleeve } & $\begin{array}{l}\text { The transverse tensile stress } \\
\text { prevents the deformation of the } \\
\text { sleeve. The transverse tensile } \\
\text { stress in the sleeve is similar in all } \\
\text { directions }\end{array}$ & $\begin{array}{l}\text { A high componential tensile stress } \\
\text { is generated in the sleeve in the } \\
\text { region opposite to the shear load }\end{array}$ & $\begin{array}{l}\text { A moderate componential tensile } \\
\text { stress is generated in the sleeve in } \\
\text { the region opposite to the } \\
\text { componential shear load }\end{array}$ \\
\hline & $\begin{array}{c}\text { Thus, a low confinement stress is } \\
\text { generated to resist the normal } \\
\text { stress generated by the spliced } \\
\text { bar. Subsequently, it controls the } \\
\text { expansion of the grout as a result } \\
\text { of splitting cracks }\end{array}$ & $\begin{array}{l}\text { A high confinement stress is } \\
\text { generated in the opposite of the } \\
\text { shear load to counter react it }\end{array}$ & $\begin{array}{c}\text { A moderate confinement stress is } \\
\text { generated in the opposite of the } \\
\text { componential shear load to } \\
\text { counter it }\end{array}$ \\
\hline Propagation of splitting cracks & $\begin{array}{l}\text { The splitting cracks propagate at } \\
\text { about the same rate in all } \\
\text { directions }\end{array}$ & $\begin{array}{l}\text { The splitting cracks propagate } \\
\text { faster along with the shear load }\end{array}$ & $\begin{array}{l}\text { The splitting cracks propagate } \\
\text { slightly faster along with the } \\
\text { componential shear load }\end{array}$ \\
\hline Bar deformation & $\begin{array}{l}\text { Bar elongates and displacement } \\
\text { longitudinally }\end{array}$ & $\begin{array}{c}\text { Bar deforms and bends towards the } \\
\text { direction of the shear force }\end{array}$ & $\begin{array}{l}\text { The bar elongates longitudinally } \\
\text { and displaces laterally in the } \\
\text { direction of the componential } \\
\text { shear load }\end{array}$ \\
\hline
\end{tabular}

(i) The yield ratio, $R_{y}$, determines whether the spliced bars yielded during the experiment. It is computed by dividing the ultimate strength of the specimen, $P_{u}$, with the nominal yield strength of the bar, $P_{s y}$ (Eq. 2). $R_{y}$ should be at least 1.0 (Ling et al. 2012).

$$
R_{s}=\frac{P_{u}}{P_{s y}}
$$

(ii) The ductility ratio, $R_{d}$, is obtained by dividing the ultimate displacement, $\delta_{u}$, with the displacement at yield, $\delta_{y}$ (Eq. 3). It demonstrates the degree of deformation underwent by the specimens before failure. $R_{d}$ should be at least 4.0 for a low-moderate seismic region.

$$
R_{d}=\frac{\delta_{u}}{\delta_{y}}
$$

(iii) The drift ratio, $R_{d f}$, indicates the degree of rotational displacement as a result of lateral load. It represents the horizontal displacement of the upper panel, $\delta_{u, f t}$, with respect to the height where the lateral load was applied, $H$ (Eq. 4). $R_{d f}$ should be at least $0.5 \%$ (Hawkins and Ghosh 2004).

$R_{d f}=\frac{\delta_{u, f t}}{H} \times 100 \%$

c. C3: The bond strength generated in the sleeve should preferably be at least the capacity of the spliced bars. For this, bar fracture failure is preferred. 
Table 7 Feasibility evaluation of the grouted splice connection in accordance to assessment criteria, with respect to each load case.

\begin{tabular}{|c|c|c|c|c|c|c|c|c|c|c|c|}
\hline & \multicolumn{11}{|c|}{ Tensile test } \\
\hline Criteria & \multicolumn{2}{|c|}{$\mathrm{C} 1$} & \multicolumn{2}{|l|}{ C2 } & \multicolumn{2}{|c|}{$\mathrm{C} 2$} & \multicolumn{2}{|r|}{ C3 } & \multicolumn{2}{|r|}{ C5 } & Remarks \\
\hline Specimen & \multicolumn{2}{|c|}{ Strength ratio, $R_{S}$} & \multicolumn{2}{|c|}{ Yield ratio, $R_{y}$} & \multicolumn{2}{|c|}{ Ductility ratio, $R_{d}$} & \multicolumn{2}{|c|}{ Failure mode ${ }^{* a}$} & \multicolumn{2}{|c|}{ Service ratio, $R_{s v}$} & \\
\hline Equation & \multicolumn{2}{|c|}{$(1)$} & \multicolumn{2}{|c|}{$(2)$} & \multicolumn{2}{|c|}{ (3) } & & & \multicolumn{2}{|c|}{$(5)$} & \\
\hline Req. & \multicolumn{2}{|l|}{$\geq 1.25$} & \multicolumn{2}{|l|}{$\geq 1.0$} & \multicolumn{2}{|c|}{$\geq 4.0$} & \multicolumn{2}{|r|}{$\mathrm{F}$} & \multicolumn{2}{|r|}{$\geq 0.75$} & \\
\hline WBS-1 & \multicolumn{2}{|l|}{0.86} & \multicolumn{2}{|c|}{0.86} & & 47 & & $\mathrm{~S}$ & & 1.00 & NA \\
\hline WBS-2 & 0.79 & & 0.79 & & 1.7 & 7 & & $\mathrm{~S}$ & & 1.00 & NA \\
\hline WBS-3 & 0.75 & & 0.75 & & & 71 & & $\mathrm{~S}$ & & 1.00 & NA \\
\hline WBS-4 & 1.31 & & 1.14 & & 14.9 & & & $\mathrm{~F}$ & & 0.89 & $\mathrm{~A}$ \\
\hline WBS-5 & 1.27 & & 1.16 & & & 64 & & $\mathrm{~S}$ & & 0.91 & A \\
\hline WBS-6 & 1.26 & & 1.13 & & & 04 & & $\mathrm{~S}$ & & 0.92 & A \\
\hline WBS-7 & 1.33 & & 1.13 & & 13. & & & $\mathrm{~F}$ & & 0.85 & $\mathrm{~A}$ \\
\hline WBS-8 & 1.33 & & 1.15 & & 14 & & & $\mathrm{~F}$ & & 0.89 & $\mathrm{~A}$ \\
\hline WBS-9 & 1.33 & & 1.14 & & 13. & & & $\mathrm{~F}$ & & 0.86 & $\mathrm{~A}$ \\
\hline & & & & & & Shear & test & & & & \\
\hline Criteria & & & & & $\mathrm{C} 2$ & $\mathrm{C} 3$ & & $\mathrm{C} 4$ & & $\mathrm{C} 5$ & Remarks \\
\hline Specimen & $\begin{array}{l}\text { Disp. at yield, } \\
\delta_{y}{ }^{* \mathrm{~b}}\end{array}$ & Avg & g. ult. disp. & Duct & $\begin{array}{l}\text { ility ratio, } \\
R_{d}{ }^{* \mathrm{c}}\end{array}$ & Failure 1 & node & Control ref & & Service ratio, $R_{s v}$ & \\
\hline Equation & & $\left(\delta_{u, s t,}\right.$ & $\begin{array}{c}\left.t, b 1+\delta_{u, s t, b 2}\right) \\
2 \\
\end{array}$ & & (3) & & & & & (5) & \\
\hline Req. & & & & & $\geq 4.0$ & $\mathrm{~F}$ & & $\sqrt{ }$ & & $\geq 0.75$ & \\
\hline WBS-1 & & & & & & & & & & & \\
\hline WBS-2 & 0.2 & & 61.0 & & 305 & $\mathrm{~S}$ & & $\mathrm{X}$ & & 0.54 & NA \\
\hline WBS-3 & & & & & & & & & & & \\
\hline WBS-4 & & & & & & & & & & & \\
\hline WBS-5 & 0.9 & & 43.6 & & 48.4 & $\mathrm{~F}$ & & $\mathrm{X}$ & & 0.28 & NA \\
\hline WBS-6 & 0.4 & & 47.5 & & 118.8 & $\mathrm{~F}$ & & $\sqrt{ }$ & & 0.26 & NA \\
\hline WBS-7 & & & & & & & & & & & \\
\hline WBS-8 & 1.2 & & 41.9 & & 34.9 & $\mathrm{~F}$ & & $\mathrm{X}$ & & 0.31 & NA \\
\hline WBS-9 & & & & & & & & & & & \\
\hline & & & & & & Flexura & test & & & & \\
\hline Criteria & $\mathrm{C} 1$ & & $\mathrm{C} 2$ & & $\mathrm{C} 2$ & $\mathrm{C} 3$ & & $\mathrm{C} 4$ & & \begin{tabular}{|c|}
$\mathrm{C} 5$ \\
\end{tabular} & Remarks*e \\
\hline Specimen & Strength ratio, $R_{s}$ & Dri & $\begin{array}{l}\mathrm{ft} \text { ratio, } R_{d f} \\
(\%)\end{array}$ & Ductil & ity ratio, $R_{d}$ & Failure 1 & mode & Control re & & Service ratio, $R_{s v}$ & \\
\hline Equation & $(1)$ & & (4) & & (3) & & & & & $(5)$ & \\
\hline Req. & & & $\geq 0.5 \%$ & & $\geq 4.0$ & $\mathrm{~F}$ & & $\sqrt{ }$ & & $\geq 0.75$ & \\
\hline WBS-1 & & & & & & & & & & & \\
\hline WBS-2 & 0.29 & & 0.36 & & 1.72 & $\mathrm{~S}$ & & $\mathrm{X}$ & & 1.00 & NA \\
\hline WBS-3 & & & & & & & & & & & \\
\hline WBS-4 & 1.07 & & 0.73 & & 2.63 & $\mathrm{~S}$ & & $\mathrm{X}$ & & 0.89 & NA \\
\hline WBS-5 & 1.35 & & 1.26 & & 6.60 & $\mathrm{~F}$ & & $\sqrt{ }$ & & 0.77 & A \\
\hline WBS-6 & 0.43 & & 0.35 & & 1.09 & $\mathrm{~S}$ & & $\mathrm{X}$ & & 1.00 & NA \\
\hline WBS-7 & & & & & & & & & & & \\
\hline
\end{tabular}


Table 7 continued

\begin{tabular}{c|c|c|c|c|c|c|c}
\hline & \multicolumn{6}{|c}{ Flexural test } & Remarks* \\
\hline Criteria & $\mathrm{C} 1$ & $\mathrm{C} 2$ & $\mathrm{C} 2$ & $\mathrm{C} 3$ & $\mathrm{C} 4$ & $\mathrm{C} 5$ \\
\hline Specimen & Strength ratio, $R_{s}$ & $\begin{array}{c}\text { Drift ratio, } R_{d f} \\
(\%)\end{array}$ & Ductility ratio, $R_{d}$ & Failure mode & Control ref. & Service ratio, $R_{s v}$ & \\
\hline Equation & $(1)$ & $(4)$ & $(3)$ & & & $(5)$ & \\
\hline WBS-8 & 1.43 & 1.85 & 7.91 & $\mathrm{~S}$ & $\sqrt{ }$ & 0.79 & $\mathrm{~A}$ \\
\hline WBS-9 & & & & & & & \\
\hline
\end{tabular}

${ }^{a} \mathrm{~S}$ - bar bond-slip failure, $\mathrm{F}$ - bar fracture failure.

b The displacement at yield is obtained from the load-displacement response of the specimens.

c The ductility ratio is computed by dividing the ultimate displacement with the average value of the displacement at yield of all specimens.

d $\sqrt{ }$ - the capacity of the specimen is equal or larger than the control specimen, $\mathrm{X}$ - the capacity is less than the control specimen.

e A-applicable, NA-non-applicable.

${ }^{\mathrm{f}}$ The italized values or conditions not fulfilling the requirements.

d. C4: The capacity of the test specimen is equal to or higher than the control specimen.

Thus, the shear and flexural capacities of the specimen should be at least 302.6 and $72.5 \mathrm{kN}$ respectively.

e. C5: The service load should be not be too low with respect to the ultimate capacity.

Therefore, the serviceability ratio, $R_{s v}$, should be at least 0.75 (Eq. 5). $R_{s v}$ shows the efficiency of the grouted splice connection to resist load. It represents the amount of capacity that is usable, $P_{s v}$, out of the ultimate capacity, $P_{u}$.

$$
R_{s v}=\frac{P_{s v}}{P_{u}}
$$

Each grouted splice connection was evaluated based on the stated assessment criteria ( $\mathrm{C} 1$ to $\mathrm{C} 5)$ with respect to each load case, as summarized in Table 7. The specimens are considered not feasible when more than one criteria are not fulfilling the requirement. The specimens which are considered feasible include: WBS-4 to 9 for tensile load; none for shear load, and; WBS-5, 8 for flexural load.

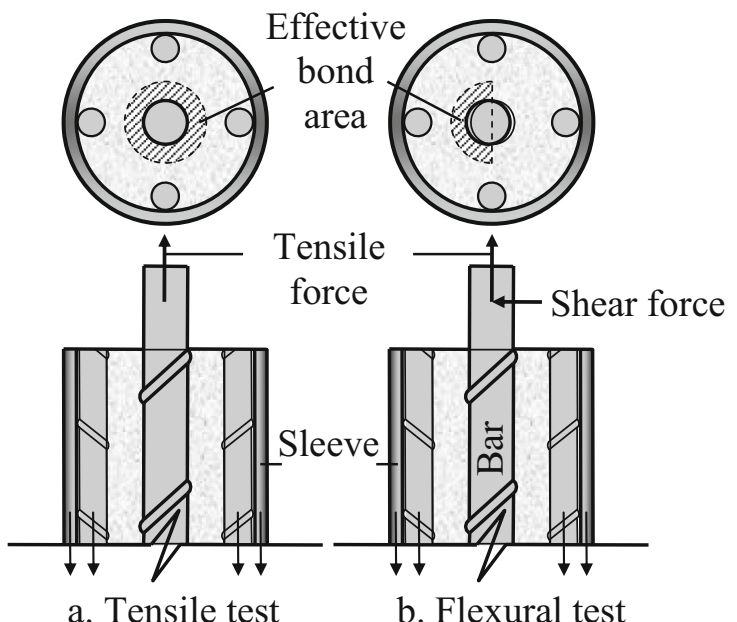

Fig. 15 Comparison of the effective bond areas under tensile and flexural loads (Ling 2011).
The grouted splice connections are not practical for resisting shear load as the usable capacity was too low, which was about $1 / 3$ of the ultimate capacity. Although the connection was able to withstand a high shear strength of about $300 \mathrm{kN}$, the bar dower action caused the connection to lose elasticity at about $100 \mathrm{kN}$. Unless it is integrated with another mechanism that is more effective in resisting shear load, such as shear keys at the dry pack joint (Rizkalla et al. 1989), the connection can only be designed at $1 / 3$ of its ultimate capacity.

The flexural load can be derived into the componential tensile and shear forces. The componential tensile load is predominant due to the slenderness of the wall panel. Flexural load seems to be more critical than the other load cases as (a) a longer bar embedded length is required, and (b) most of the specimens enduring bar fracture failure under the other load cases ended up with the bar bond-slip failure under flexural load.

This phenomenon could be due to the decrease of the effective bond region as a result of the redistribution of the normal and confinement stresses described in Fig. 14 and Table 6. The componential shear force of the flexural load pushed the spliced bar towards the sleeve wall as it was being pulled out by the componential tensile load. Only some areas were involved in resisting the pullout force, as shown in Fig. 15. For that, fewer grout keys contributed to the bond strength, and the connection failed earlier than when subjected to pure tensile load.

Through the feasibility assessment, the following is found:

a. Grouted splice connection is effective in resisting tensile load. The bar embedded length of $125 \mathrm{~mm}\left(8 d_{b}\right)$ would be applicable regardless of the size of the sleeve as long as the sleeve diameter does not exceed $75 \mathrm{~mm}\left(5 d_{b}\right)$.

b. The connection is not as effective when subjected to shear and flexural loads compared with tensile load. To resist flexural load, a longer bar embedded length of $175 \mathrm{~mm}\left(11 d_{b}\right)$ is required. It is not recommended to resist shear load without any shear keys at the dry pack joint. 


\section{Conclusion}

Based on the response of Welded Bar Sleeve (WBS) under tensile, shear and flexural loads, it is good at resisting the longitudinal load, but not as effective in resisting the lateral load. For that, a longer bar embedded length is required to resist flexural load, and it is not recommended for resisting shear load due to unpractically low serviceability.

This study reveals that a connection found feasible under tensile load may not necessarily be feasible under shear and flexural loads. This raises an important question whether the tensile test can be a rule of thumb to determine the feasibility of a grouted splice sleeve as a connection for precast concrete structure, noting that it may be subjected to various kinds of load. To-date, the industry is still very much relying on it as the main assessment criteria to determine the feasibility of a grouted splice connection.

We believe that the stress distribution in WBS varies slightly with respect to different load cases. It may be conceptually logical, but the internal response illustrated in this paper is still hypothetical. Finite element analysis may be required to validate that.

It would be a significant breakthrough if a reliable correlation among tensile, shear and flexural loads could be established through empirical, analytical or numerical methods. By then, tensile test can be used to determine the behaviour and feasibility of the connection under shear and flexural loads. The test is cheaper, easier to conduct and less time consuming.

The sleeve diameter seems to affect the tensile capacity of the connection. However, based on the amount of data available as obtained from the limited number of specimens, it is still uncertain whether it is also affecting the performance of the connection when subjected to lateral loads.

We believe that (a) the eccentricity of the spliced bar in WBS would have little impact on the bond strength under tensile load, and (b) the effect could be quite significant for shear and flexural loads. However, we are unable to confirm this hypothesis as all the results in this study assume that all specimens are installed without any eccentricity.

The proposed grouted splice connections are yet to be tested under seismic, fatigue and constant (creep) loads. At the current stage, it is still uncertain of their feasibility under these circumstances.

\section{Acknowledgements}

We thank the financial support of Construction Industry Research Institute of Malaysia (CREAM) and Construction Industry Development Board (CIDB) through Research Grant Vot 73713.

\section{Open Access}

This article is distributed under the terms of the Creative Commons Attribution 4.0 International License (http:// creativecommons.org/licenses/by/4.0/), which permits un restricted use, distribution, and reproduction in any medium, provided you give appropriate credit to the original author(s) and the source, provide a link to the Creative Commons license, and indicate if changes were made.

\section{References}

Abd. Rahman, A. B., Ling, J. H., \& Ibrahim, I. S. (2010). Performance of grouted sleeve connectors subjected to incremental tensile loads. Malaysian Construction Research Journal (MCRJ), 6, 39-55.

AC-133. (2008). Acceptance criteria for mechanical connector systems for steel reinforcing bars. Brea:ICC Evaluation Service, Inc.

ACI-117. (1990). Standard Specifications for Tolerances for Concrete Construction and Material. ACI Journal. ACI Committee 117.

ACI-318. (2002). Building code requirements for structural concrete and commentary. Farmington Hills, MI: American Concrete Institute

Aldin Hosseini, S. J., \& Abd. Rahman, A. B. (2013). Analysis of spiral reinforcement in grouted pipe splice connectors. Građevinar, 65, 537-546.

Aldin Hosseini, S. J., \& Abd. Rahman, A. B. (2016). Effects of spiral confinement to the bond behavior of deformed reinforcement bars subjected to axial tension. Engineering Structures, 112, 1-13.

Aldin Hosseini, S. J., Abd. Rahman, A. B., Osman, M. H., et al. (2015). Bond behavior of spirally confined splice of deformed bars in grout. Construction and Building Materials, 80, 180-194.

Alias, A., Sapawi, F., Kusbiantoro, A., et al. (2014). Performance of grouted splice sleeve connector under tensile load. Journal of Mechanical Engineering and Sciences (JMES), 7, 1096-1102.

Alias, A., Zubir, M. A., Shahid, K. A., et al. (2013). Structural performance of grouted sleeve connectors with and without transverse reinforcement for precast concrete structure. Procedia Engineering, 53, 116-123.

Ameli, M. J., Parks, J. E., Brown, D. N., et al. (2015). Seismic evaluation of grouted splice sleeve connections for reinforced precast concrete column-to-cap beam joints in accelerated bridge construction. PCI Journal, 60, 80-103.

ASTM A. (2005). In: ASTM (ed). ASTM A1034/A Standard test methods for testing mechanical splices for steel reinforcing bars. West Conshohocken, PA: ASTM International.

Belleri, A., \& Riva, P. (2012). Seismic performance and retrofit of precast concrete grouted sleeve connections. PCI Journal, 57, 97-109.

BS8110-1:1997. (1997). Structural use of concrete-Part 1: Code of practice for design and construction BS 8110 . British Standards BSI.

E564-06 A. (2006). Standard practice for static load test for shear resistance of framed walls for buildings. ASTM International. 
Einea, A., Yamane, T., \& Tadros, M. K. (1995). Grout-filled pipe splices for precast concrete construction. Precast/ Prestressed Concrete Institute Journal, 40, 82-93.

Haber, Z. B., Saiidi, M. S., \& Sanders, D. H. (2014). Seismic performance of precast columns with mechanically spliced column-footing connections. ACI Structural Journal, 111, $1-12$.

Haber, Z. B., Saiidi, M. S., \& Sanders, D. H. (2015). Behavior and simplified modeling of mechanical reinforcing bar splices. ACI Structural Journal, 112, 179-188.

Hawkins, N. M., \& Ghosh, S. K. (2004). Acceptance criteria for special precast concrete structural walls based on validation testing. PCI Journal, 49, 78-92.

Henin, E., \& Morcous, G. (2015). Non-proprietary bar splice sleeve for precast concrete construction. Engineering Structures, 83, 154-162.

Jansson, P. O. (2008). Evaluation of grout-filled mechanical splices for precast concrete construction. $R-1512$. Michigan: Michigan Department of Transportation MDOT.

Kim, Y.-M. (2000). A study of pipe splice sleeves for use in precast beam-column connections. Faculty of the Graduate School, The University of Texas at Austin, 116.

Koushfar, K., Abd. Rahman, A. B., \& Ahmad, Y. (2014). Bond behavior of the reinforcement bar in glass fiber-reinforced polymer connector. Gradevinar, 66, 301-310.

Lin, F., \& Wu, X. (2016). Mechanical performance and stressstrain relationships for grouted splices under tensile and cyclic loadings. International Journal of Concrete Structures and Materials, 10, 435-450.

Ling, J. H. (2011). Behaviour of grouted splice connections in precast concrete wall subjected to tensile, shear and flexural loads (p. 276). Skudai, Johor: Department of Structural and Material, Faculty of Civil Engineering, Universiti Teknologi Malaysia.

Ling, J. H., Abd. Rahman, A. B., Abd. Hamid, Z. (2008). Failure modes of aluminium sleeve under direct tensile load. In 3rd International Conference on Postgraduate Education (ICPE-3). Penang: Sarawak Universiti Sains Malaysia (USM).

Ling, J. H., Abd. Rahman, A. B., \& Ibrahim, I. S. (2014). Feasibility study of grouted splice connector under tensile load. Construction and Building Materials, 50, 530-539.

Ling, J. H., Abd. Rahman, A. B., Ibrahim, I. S., et al. (2012). Behaviour of grouted pipe splice under incremental tensile load. Construction and Building Materials, 33, 90-98.

HY, Loh. (2008). Development of grouted splice sleeve and its performance under axial tension (p. 80). Skudai, Johor:
Faculty of Civil Engineering, Universiti Teknologi Malaysia.

Rizkalla, S. H., Serrette, R. L., Heuvel, J. S., et al. (1989). Multiple shear key connections for precast shear wall panels. PCI Journal, 34, 104-120.

Sayadi, A. A., Abd. Rahman, A. B., Jumaat, M. Z., et al. (2014). The relationship between interlocking mechanism and bond strength in elastic and inelastic segment of splice sleeve. Construction and Building Materials, 55, 227-237.

Sayadi, A. A., Abd. Rahman, A. B., Sayadi, A., et al. (2015). Effective of elastic and inelastic zone on behavior of glass fiber reinforced polymer splice sleeve. Construction and Building Materials, 80, 38-47.

Seo, S.-Y., Nam, B.-R., \& Kim, S.-K. (2016). Tensile strength of the grout-filled head-splice-sleeve. Construction and Building Materials, 124, 155-166.

Soudki, K. A. (1994). Behaviour of horizontal connections for precast concrete load-bearing shear wall panels subjected to reversed cyclic deformations (p. 656). Winnipeg, MB: Structural Engineering Division, Department of Civil \& Geological Engineering, University of Manitoba.

Soudki, K. A., Rizkalla, S. H., \& LeBlanc, B. (1995). Horizontal connections for precast concrete shear wall subjected to cyclic deformations part 1: Mild steel connections. PCI Journal, 40, 78-96.

Tastani, S. P. (2002). Experimental evaluation of direct tension-pullout bond test. In International Symposium Bond in Concrete-from research to standard, Budapest.

Tibbetts, A. J., Oliva, M. G., \& Bank, L. C. (2009). Durable fiber reinforced polymer bar splice connections for precast concrete structures. COMPOSITES \& POLYCON.

Tullini, N., \& Minghini, F. (2016). Grouted sleeve connections used in precast reinforced concrete construction-experimental investigation of a column-to-column joint. Engineering Structures, 127, 784-803.

West, J. S., Soudki, K. A., \& Rizkalla, S. H. (1993). Behaviour of horizontal connections for precast concrete load bearing shear wall panels subjected to reversed cyclic loading. Winnipeg, MB: Department of Civil Engineering, University of Manitoba.

Zhu, Z., \& Guo, Z. (2016). Experiments on hybrid precast concrete shear walls emulating monolithic construction with different amounts of posttensioned strands and different debond lengths of grouted reinforcements. Advances in Materials Science and Engineering, 2016, 13. 